\title{
Respiratory Diseases in Children-Oral Findings and Dentist Approaches
}

\section{Gogce 0, Caliskan S*, Tuloglu N and Bayrak S}

Department of Pediatric Dentistry, Eskisehir Osmangazi University, Turkey

*Corresponding author: Secil Caliskan, Assistant Professor, Department of Pediatric Dentistry, Eskisehir Osmangazi University, Eskisehir, Turkey, Tel: +905448073311, Fax: +902222391273; Email: sclctn@hotmail.com

\section{Review Article \\ Volume 5 Issue 1}

Received Date: February 05, 2020

Published Date: February 18, 2020

DOI: $10.23880 /$ oajds-16000244

\section{Abstract}

Oral and dental health may be adversely affected in children with respiratory diseases. Tooth decay, tooth erosion, tooth enamel problems, gingivitis and periodontal diseases are more common in these children. Oral and dental health problems in these patients may be related to the side effects of the disease or related to the drugs they use. Especially in diseases such as asthma and cystic fibrosis, problems related to oral and dental health are common and it is important to refer these patients to the dentist in the early period.

In this review, common oral findings related to respiratory diseases will be discussed and the precautions and treatment approaches that the dentist should take in this case will be discussed.

Keywords: Asthma; Intraoral findings; Pediatric dentistry; Respiratory diseases

\section{Abbreviations: OSA: Obstructive Sleep Apnea.}

\section{Introduction}

Respiratory diseases in children can cause conditions that threaten oral and dental health. It is known that asthma is a risk factor for dental caries in children. In addition, it has been reported that oral and dental problems may occur in children with cystic fibrosis due to changes in the content of secretions and high calorie nutrition of patients. It is possible to recognize the problems of dental health, such as dental caries and periodontal diseases, by performing dental controls of the children from an early age [1-3].

\section{Obstructive Sleep Apnea (OSA)}

OSA is a syndrome characterized by recurrent upper respiratory tract full or partial obstructions during sleep, usually accompanied by reduced oxygen saturation and awakening [4].

\section{Intraoral Findings of OSA}

Dental caries, dental erosions and periodontal diseases are seen due to xerostomy in children with OSA (Figure 1) [3]. Periodontal diseases may develop especially in patients with OSA due to nasopharyngeal obstruction due to adenoid and tonsillar hypertrophy. Periodontal problems may occur as a result of snoring and mouth breathing in children with neuromuscular insufficiency without adenotonsillar hypertrophy. Bacteria that can be isolated from dental plaque (such as pseudomonas aeruginosa, staphylococcus aureus) have been reported to have a high risk of pneumonia in patients hospitalized in the intensive care unit of the hospital, and periodontitis has been reported to trigger lung infection [3,5]. 


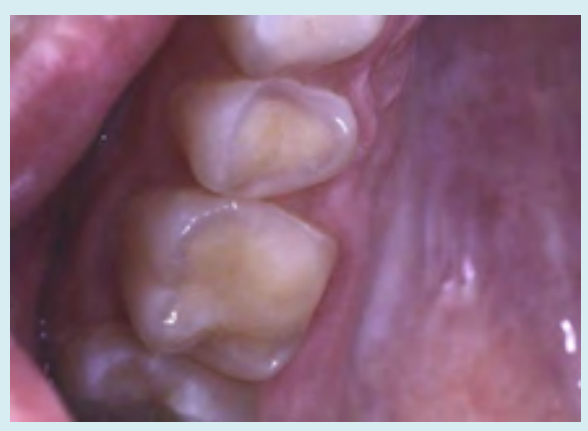

Figure 1: Tooth erosion [1].
Children with OSA usually have craniofacial anomalies [6]. Long-term exposure of children to non-invasive mechanical ventilation causes problems in facial development including maxilla [1].

\section{Dentist Approach in Children with OSA}

Correction of oral hygiene is of great importance in children with OSA and correction of oral hygiene is of paramount importance in order to prevent lung infections due to aspiration of microorganisms in the teeth $[3,5]$. Orthodontic approach is important in these children in terms of craniofacial anomalies [1].

\section{Asthma}

Asthma is a chronic disease of the bronchi characterized by repetitive and temporary breathing difficulties caused by the underlying agent. Allergic sensitivities are usually seen in asthmatic patients. Clinical symptoms of asthma include wheezing in the chest, particularly dry and stubborn cough in the morning, shortness of breath, cough or wheezing due to effort or allergen [7]. Allergic rhinitis is diagnosed in approximately $80 \%$ of asthma patients [3].

Aspirin, acetaminophen (paracetamol), non-steroid antiinflammatory drugs (ibuprofen and naproxen), mefenamic acid with antiinflammatory, analgesic and antipyretic effects, and pentazocin, which is a psychiatric drug, can cause asthma attacks. Penicillin allergy is also common in children with asthma [8].

\section{Intraoral Findings of Asthma}

Mouth breathing occurs in children with asthma due to nasal obstruction. Xerostomy is observed in these patients due to both decongestant and antihistaminic use and oral respiration. In addition, these children have an increased incidence of caries, especially in permanent teeth, due to oral respiration and the use of inhalers to reduce the amount of saliva. Furthermore, increased susceptibility to increased calculus, hyperplastic gingivitis (Figure 2), dental erosion, bad breath, atypical ulceration, mucosal atrophy and opportunistic infections (candida) are also seen $[3,7,9]$.

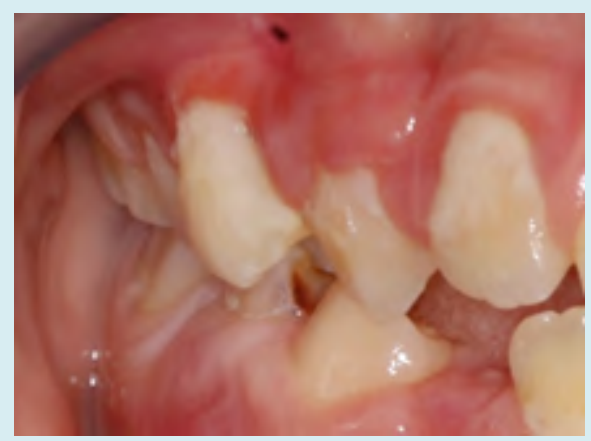

Figure 2: Hyperplastic gingivitis.

In children with allergic rhinitis, findings such as deep palatinal arch, tongue protrusion and overbite are observed [7].

The majority (approximately $80 \%$ ) of beta 2 -antagonist inhalers of asthma medicines are kept in the oral cavity [10]. Inhalation powder usually contains a sugar such as lactose [11]. Inhalers reduce the amount of saliva and increase carotid bacteria and cause caries. This is exacerbated by the lack of mouth rinsing, especially after taking the medication before sleeping at night $[5,7]$. In addition, acid secretion increases with the effect of asthma medications and gastroesophageal reflux in patients and the risk of developing dental erosion increases proportionally [3]. The use of long-term topical steroide-containing sprays increases the susceptibility to oral candida infections, but also leads to adrenal suppression [7].

\section{Dentist Approach in Children with Asthma}

When taking anamnesis of asthmatic children, especially the frequency of asthma attacks, drugs used during longterm or acute attacks and the time of the last acute asthma attack should be learned [12].

In children with asthma, successful dental treatment can be achieved by eliminating the increased tissue reaction to specific or non-specific stimuli. With the common approach of pediatrician and pediatric dentist, specific factors should be identified, stress should be reduced and prepared for emergency [10]. Because asthma patients are prone to allergies, dental polishing products, acrylics and similar substances should be used with caution. In the dentistry clinic, potential allergens should be evaluated and measures to reduce fear should be taken as asthma attacks due to 
excessive fear can be triggered [12]. During treatment, the patient is in a supine position, the position of the saliva ejector, and cotton rolls may cause an attack. Therefore, patients should be treated by sitting upright or semi-upright. Preoperative bronchodilators may be used to prevent acute symptoms during the procedure [10]. When acute asthma attack develops during the procedure;

a) Dental treatment should be stopped, the patient should be seated or extended in a comfortable position.

b) The airway should be kept open and inhaled beta-2 agonist spray should be given.

c) Oxygen should be given by nose mask or cannula.

d) If no improvement is observed and the patient is deteriorating, subcutaneous epinephrine should be administered and the patient should be referred to the hospital [12].

Patients should be advised that the mouth should be rinsed with water after each steroid inhalation.

It is very important to prevent the development of caries by correcting oral hygiene and treating allergic rhinitis [7]. Due to the high risk of caries, regular preventive treatments (fluoride treatments) should be performed [7].

Since there may be a risk of developing airway obstruction and spreading infection deeper in upper and lower respiratory diseases, treatment should be postponed until the control of asthma under general anesthesia. In these patients, general anesthesia can be performed only under special conditions and by taking detailed precautions. Narcotics cause histamine release and cause respiratory depression. When drugs that cause histamine release are used, antihistamine should be given first to prevent histamine release. When sedation is required, nitrous oxide/ oxygen sedation is recommended. Other sedatives may cause respiratory failure [12].

\section{Cystic Fibrosis}

Cystic fibrosis is an autosomal recessive genetic disorder characterized by hyperviscous secretion in the respiratory system and gastrointestinal tract. Sweat glands, hepatobiliary system and reproductive organs are most affected. Developmental retardation is observed over time as it occurs with birth [7].

\section{Intraoral Findings of Cystic Fibrosis}

It has been reported that dental plaque formation and defects in tooth enamel develop due to long-term antibiotic use in children with cystic fibrosis [13]. The risk of caries development is increased in patients who do not pay attention to oral hygiene and nutrition as a high-energy but caretogenic diet is required for normal maintenance of growth and development in cystic fibrosis [3]. Frequent use of antibiotics, administration of pancreatic enzymes, and decreased salivary calcium and protein levels are other factors that predispose to caries development. Steroid use can change the oral flora and cause extrinsic tooth discoloration and candidiasis. Clogging of the nasal cavity and maxillary sinus may develop in children with cystic fibrosis after recurrent infections. This may lead to an increase in the amount of mouth opening and anterior open closure and a deep palate dome [10]. As with other mouth breathing patients, these patients have open closure and may require orthodontic treatment [7].

\section{Dentist Approach in Children with Cystic Fibrosis}

The dentist should avoid exacerbating the underlying disease in patients with cystic fibrosis. It should be noted that gases with high viscosity, such as nitrous oxide/oxygen, may dehydrate respiratory fluids and cause further blockage and infection. Rubber-dam can be used to reduce possible aspiration of air droplets from dental hand pieces [10].

\section{Tuberculosis}

Mycobacterium tuberculosis is the causative agent of the disease, and these bacilli have two major strains, bovine and human strains. Bacteria of human strain often cause pulmonary tuberculosis. In countries where bovine tuberculosis is widespread, bone, joint and intestinal tuberculosis is common in children who drink milk from these cows [14].

Tuberculosis can be transmitted directly through lung disease, digestive tract and skin infection [14]. Inhalation of dust or droplets containing bacteria directly into the lungs leads to infections of Mycobacterium Tuberculosis with human strains 14 . Although the lungs are the most commonly involved organs, they are also common in other organs of the body (lymph nodes, kidney, spleen, liver, intestine, brain and meninges) [14].

As with many infectious diseases, the development and prognosis of tuberculosis depends on the number of bacilli entering the body, virulence, the route of entry into the body and the resistance of the host. Fatigue, diabetes, nutritional deficiencies, occupational difficulties, psychological stresses, alcoholism and environmental factors leading to decreased body resistance are factors that increase the incidence of tuberculosis. Apart from these, age and gender are the other factors affecting the development of tuberculosis. Infants, adolescents and elderly people can easily catch the infection, while children in the 5-14 age group are highly resistant to 
the disease [14].

\section{Intraoral Findings of Tuberculosis}

Typical oral manifestations of tuberculosis patients; pain and ulceration in the mucosa, diffuse inflammatory lesions, granulomas and fissures. The most affected tongue is buccal mucosa, gingiva, mouth base, soft and hard palate. Delay in wound healing is observed in patients with active tuberculosis. The socket is filled with an easily bleeding granulation tissue [15-17].

\section{Dentist Approach in Children with Tuberculosis}

Since the presence of tuberculosis lesions in the mouth is important in tuberculosis patients, it should be investigated whether the patient is in active tuberculosis period or not. Patients with active symptoms (fever, weakness, night sweats, weight loss, sputum) should have a delayed dental procedure until the sputum culture is $(-)$ because patients with tuberculosis lesions in the mouth have high infectiousness. Because the bacillus in the sputum can easily settle into traumatic lesions of the oral mucosa and tongue, traumatic conditions such as rotten teeth or incompatible dentures should be treated. As dentists are at risk for tuberculosis contagiousness, masks, gloves and strong aspirators should be used. Sterilization of instruments used in patient's needs to be very careful and instruments that cannot be sterilized should be sterilized with formaldehyde or ethylene oxide gases. Since suppurative periodontal lesions may cause bacteremia even with chewing or tooth brushing, they should be treated as they may exacerbate the picture of tuberculosis [7].

\section{Bronchopulmonary Dysplasia}

Bronchopulmonary dysplasia has been described as one of the most important sequelae of acute respiratory distress in neonatal intensive care units and occurs in approximately $30 \%$ of infants with a birth weight of less than a thousand grams [18]. Although bronchopulmonary dysplasia is a problem of premature infants, it is defined as a chronic disease of the lungs in timely babies, older children and even adults. In neonatology, it is expressed as the continuation of oxygen dependence and/or need for assisted ventilation in the newborn due to pulmonary causes [19].

\section{Intraoral Findings of Bronchopulmonary Dysplasia}

Hohoff, et al. 20 reported that the development of palate in preterm infants was affected by intubation, feeding type, diet, nasogastric feeding tube, tube characteristics, head structure and birth weight in premature and low birth weight babies. Long-term oral intubation is known to produce asymmetries with changes in the palate structure. In long- term follow-up of neonates in intensive care units, anomalies of the head bones are observed. Nasal oxygen administration or nasogastric tube feeding leads to nasal obstruction and mouth breathing, but it causes OSA due to deepening of palate dome and enlargement of adenoid structure. In infants with low body weight, it is reported that the base of the head is short and the maxilla is smaller, as well as the retrognatic face structure $[3,20,21]$.

\section{Conclusion}

Regular dental examinations of children with respiratory diseases are important in the early diagnosis of diseases and maintenance of oral and dental health. In the maintenance of oral and dental health of these children, it is important that the physicians following the child and the dentists cooperate.

\section{References}

1. Widmer RP (2010) Oral health of children with respiratory diseases. Paediatr Respir Rev 11(4): 226232.

2. Stensson M, Wendt LK, Koch G, Oldaeus G, Birkhed D (2008) Oral health in preschool children with asthma. Int J Paediatr Dent 18(4): 243-250.

3. Emiralioğlu N, Özçelik HU (2016) Çocuklarda Akciğer Hastalıkları ve Ağız ve Diş Sağlı̆̆ı. Turkiye Klinikleri Journal of Pediatric Dentistry-Special Topics 2(2): 23-27.

4. Başoğlu ÖK (2017) Obstrüktif Uyku Apne Sendromu Klinik Özellikleri ve Tanısı. Turkiye Klinikleri Pulmonary Medicine-Special Topics 10(1): 7-13.

5. Ersin NK, Gülen F, Eronat N, Cogulu D, Demir E, et al. (2006) Oral and dental manifestations of young asthmatics related to medication, severity and duration of condition. Pediatr Int 48(6): 549-554.

6. Ivanhoe JR, Lefebvre CA, Stockstill JW (2007) Sleep disordered breathing in infants and children: a review of the literature. Pediatr Dent 29(3): 193-200.

7. Cebeci A (2009) Cebeci Oral Diagnoz ve Radyoloji Kitapları Serisi: Hastalıkların İncelenmesi ve Güncel Dişhekimi Yaklaşımları, Ankara $1^{\text {st }}$ (Edn.), pp: 33-152.

8. Karaca İR, Öztürk DN (2016) Dişhekimliği açısından riskli sistemik hastalıklar ve bu hastalıklara bağlı oluşabilecek acil durumlar: bölüm 1- sistemik hastalıklar. Atatürk Üniversitesi Diş Hekimliği Fakültesi Dergisi 16(1): 147156.

9. Aral K, Aral CA, Ersin Kalkan R (2016) Astım ve Ağız Sağlığı. Ege Üniversitesi Dişhekimliği Fakültesi Dergisi 


\section{Open Access Journal of Dental Sciences}

37(2): 42-46.

10. Koch G (2009) PS: Çocuk Dişhekimliğine Klinik Yaklaşım. In: Açıları ÇASB, (Eds.), Kronik Sağlık Sorunları olan Çocuklar: Ağız sağlığına etkileri, $2^{\text {nd }}(E d n$.), Medya Yayın Grubu, Istanbul, pp: 315-330.

11. Çelenk S, Ayna B (2019) The effect of the asthma disease in children on the dental caries çocuklarda astım hastalığının diş çürügü üzerine etkisi. Dental and Medical Journal-Review 1(1): 37-42.

12. Zhu JF, Hidalgo $\mathrm{H}$, Holmgreen W, Redding SW, Hu J, et al. (1996) Dental Management of Children with Asthma. Pediatr Dent 18(5): 363-370.

13. Narang A, Maguire A, Nunn J, Bush A (2003) Oral health and related factors in cystic fibrosis and other chronic respiratory disorders. Arch Dis Child 88(8): 702-707.

14. Bulut ÖE (2005) Diş Hekimliği Pratiğini İlgilendiren İnfeksiyözHastalıklar,UlusalSterilizasyon Dezenfeksiyon Kongresi $4^{\text {th }}$ (Edn.), Bilimsel Tıp Yayınevi, Ankara.

15. Von Arx D, Husain A (2001) Oral medicine: Oral tuberculosis. British Dental Journal 190(8): 420.
16. Kakisi OK, Kechagia AS, Kakisis IK, Rafailidis PI, Falagas ME (2010) Tuberculosis of the oral cavity: a systematic review. Eur J Oral Sci 118(2): 103-109.

17. Eng HL, Lu SY, Yang CH, Chen WJ, Jaconson J, et al. (1996) Oral tuberculosis. Oral Surgery, Oral Medicine, Oral Pathology, Oral Radiology, and Endodontology 81(4): 415-420.

18. Hay WW LM, Deterding RR, Abzug MJ (1982) Current Diagnosis and Treatment; Lange. USA, pp: 533.

19. Sarıcı SÜ (2006) Bronkopulmoner displazi: tanımı, patogenezi, epidemiyolojisi ve patolojisinde yeni görüşler. Çocuk Sağlığı ve Hastalıkları Dergisi 49(1): 6070.

20. Hohoff A, Rabe H, Ehmer U, Harms E (2005) Palatal development of preterm and low birth weight infants compared to term infants-What do we know? Part 2: The palate of the preterm/low birthweight infant. Head \& Face Medicine 1(1): 9.

21. Macey Dare L, Moles D, Evans R, Nixon F (1999) Longterm effect of neonatal endotracheal intubation on palatal form and symmetry in 8-11-year-old children. The European Journal of Orthodontics 21(6): 703-710. 